\title{
The Development Path Choice of the Modern Service Industry in the Resource-Dependent Cities
}

\author{
Tang Shuling \\ Research institute of higher vocational education, Tangshan Vocational and Technical College, Tangshan, Hebei Province, China \\ shuling.t@126.com
}

\begin{abstract}
In some resource-dependent cities, modern service industry is a very low proportion. The development of second industry is inharmonious with service industry. The levels of information, marketization and industrialization are lower. In this paper, we used empirical and normative analysis to make some innovative ideas. That is to exert governmental functions, to improve the development environment of modern service industry, to carry out the diversification strategy, to attach great importance on training talents, to expand developing space, to enhance the innovation of system and mechanism. Then, all that will highlight the core position of modern service industry in the economic society development.

Index Terms - resource-dependent cities, modern service industry, path choice

\section{Introduction}

With the industrial structure of the world changing from the "industrial economy" to "service economy", our country's traditional industries begin to accelerate transformation and upgrade, especially in the service sector. The development of modern service sector is increasingly manifested. The development level of it has become the most important mark to judge the city modernization level, and also the most important task to improve city core competitiveness.
\end{abstract}

\section{The Summary of Modern Service Industry}

The concept about modern service industry abroad, first appeared in the book, The Knowledge and Distribution in the United States. The author is an American scholar, Machlup. He thinks that the modern service industry mainly includes four sectors, education, scientific research, communication media, and information service. He highlighted the knowledgeability and information service character of the modern service industry. Based on the 15th National Party Congress report, the concept of modern service industry in China was proposed. The modern service industry which has been born in the stage of developed industrialization, mainly relies on information technology and modern management concepts and assembles information and knowledge intensive service sectors.

Domestic Scholar, Hu Qiheng(2003)considered that the modern service industry essentially comes from the economic development, social progress, division of labor and specialization in society, etc. Science and technology, especially the information technology plays an important role for the modern service industry. Xu Guoxiang(2004),designed the statistical criteria of modern service industry, and considered that it is the producer services industry. LuWei(2005) studied the development problem of the modern service industry in urbanization process. Liu Huiqun (2005) analyzed the world development trends, and proposed that the information-based networking is the main feature[1].

Compared with the traditional service industry, the modern service industry is the department which supported by the modern science and technology, especially the information network technology, and also guided by modern management concept, based on the modern operation mode, service mode, organizational form,method and management style., to provide services for modern life and production. It not only concludes the new service industry, but also the transformation and upgrade of traditional service industry. The modern service industry is knowledgeability, added-value, high-quality, high-tech character and new type, etc. It is the sustainable development industry of Knowledge and Technology, low consumption of resource and little environmental pollution.

\section{The Current Situation of Modern Service Industry in the Resource-Dependent Cities}

\section{A. The low proportion of modern service industry in the} resource-dependent cities

According to the kinds of resources, the resourcedependent cities in our country can be divided into six types: coal city, nonferrous metallurgical city, ferrous metallurgical city, petroleum city, forest city, and other cities. The widespread phenomenon in the resource-dependent cities, is the small contribution rate of modern service industry to the service industry. The proportion of current Global Services(tertiary industry)in regional GDP is over $60 \%$,advanced countries is over $70 \%$, and the modern service industry accounts for more than 50\%in service output, according to the World Bank. At home, the proportion of modern service industry in the resource-dependent cities is low. Now, we select and analyze the sample of the coal cities which account for high proportion.

Table 1 shows the proportion of third industry structure in the coal cities, such as Tangshan, Handan, Datong, Chifeng, Zaozhuang, are $31.7 \%, 33.7 \%, 44 \%, 29.5 \%$ and $34 \%$, they are lower than the national average $44.6 \%$. The proportion of modern service in the service industry of Tangshan is $24.2 \%$, Guangdong is $50.1 \%$,it is far lower than that. From that we know the resource-dependent cities boost investment of modern service(tertiary industry)and determine to develop it. 
TABLE I The Contrast Table of Coal Cities in the Whole County 2012

\begin{tabular}{|c|c|c|c|c|}
\hline \multicolumn{1}{|c|}{ City } & $\begin{array}{c}\text { Regiona } \\
\text { 1 GDP }\end{array}$ & $\begin{array}{c}\text { The value- } \\
\text { added of } \\
\text { tertiary } \\
\text { industry }\end{array}$ & $\begin{array}{c}\text { Third industry } \\
\text { structure }\end{array}$ & $\begin{array}{c}\text { The tertiary } \\
\text { industry investment } \\
\text { accounted for all } \\
\text { fixed-assets }\end{array}$ \\
\hline Tangshan & 5861.63 & 1859.02 & $9.1: 59.2: 31.7$ & 51.2 \\
\hline Handan & 3023.7 & 1019 & $12.7: 53.6: 33.7$ & 44.9 \\
\hline Datong & 931.3 & 409.4 & $5.3: 50.7: 440$ & 55.2 \\
\hline Chifeng & 1569.35 & 462.93 & $15.1: 55.4: 29.5$ & 39.4 \\
\hline Zaozhuang & 1702.9 & 578.59 & $7.8: 58.2: 34$ & 50.1 \\
\hline
\end{tabular}

Data source: Statistical Information Net of China

$B$. the development of secondary industry and modern service industry (tertiary industry) in the resource-dependent cities is imbalanced

The disharmonious phenomena are widespread in industrial structure of resource-dependent cities. Tangshan, for example, Figure 1 from CNBS and Tangshan Statistics shows that the proportion of secondary industry in regional GDP is higher $10 \%$ than the national level, the highest is $60.06 \%$, the lowest is $51.74 \%$.In the whole country the highest and lowest are $47.9 \%$ and $44.8 \%$.From this we know that the proportion of secondary industry in regional GDP is much higher than the national level. The proportion of third industry structure (tertiary industry)in the whole industrial structure of the country and Tangshan, about highest and lowest, the before is $44.6 \%$ and $40.4 \%$, the after is $32.79 \%$ and $29.84 \%$. Tangshan is lower $10 \%$ than the national level, China is at an increasing rate, but Tangshan is steady.

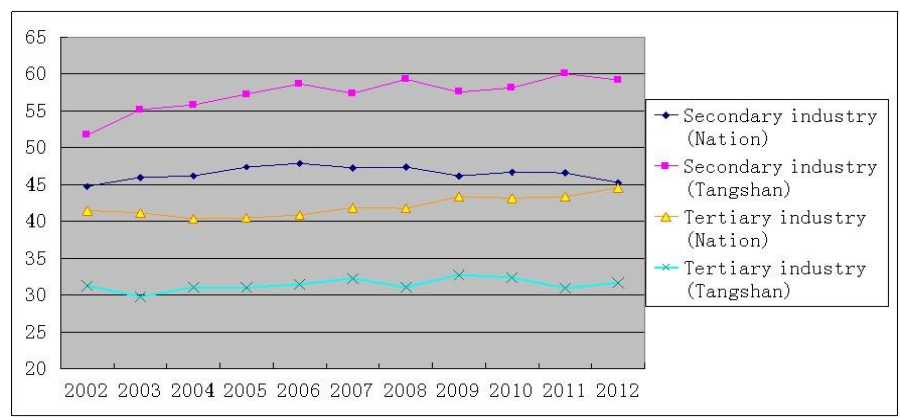

Data source: China Statistical Yearbook and Tangshan Statistical Yearbook

Fig. 1 The proportion of secondary industry and service industry in the regional GDP about the whole nation and Tangshan2002-2012

Figure 2 shows the proportion of secondary industry and service industry (tertiary industry) in the regional GDP of Tangshan 2003-2012, for the highest and lowest, the before are $60.06 \%$ and $55.2 \%$, the after are $32.79 \%$ and $29.84 \%$. The proportion of secondary industry in Tangshan is too large, and the service industry (tertiary industry) is too small, so they are imbalanced in the development.

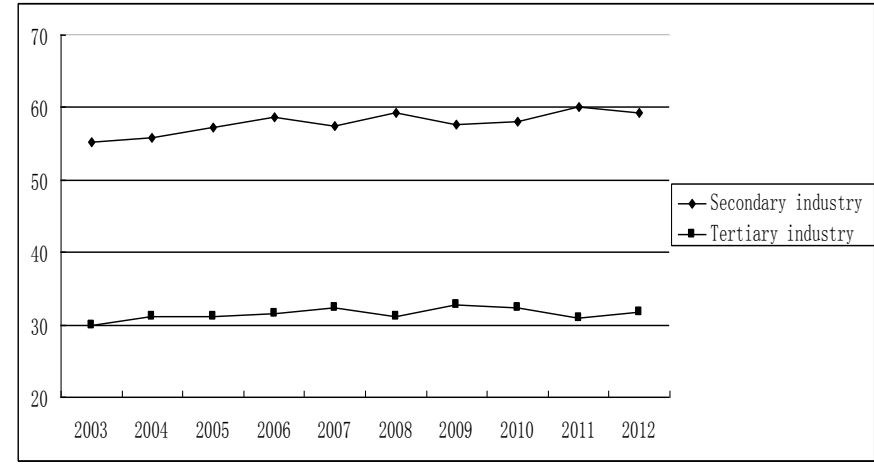

Data source: China Statistical Yearbook and Tangshan Statistical Yearbook

Fig. 2 The proportion of secondary industry and service industry (tertiary industry) in the regional GDP of Tangshan

C. the low levels in information, market, industry of resourcedependent cities

Information service industry are the main force of the national information society and a booster to achieve the transformation and upgrade of traditional industry. The modern services rely on it. If the information services are underdeveloped, they hinder the development of modern services industry. The resource-dependent cities face the low marketization and industrialization level of the modern service, lacking of innovation power, and less competitive. Although most of the modern services field has changed from social welfare into commercialized-running, the all-round development system and mechanism lacked flexibility. For most of productive services in the modern services are decommodification, non-social-oriented, the result is that the low efficiency of various facilities and the waste of economic resources. At the same time, the marketing elements of labor, technology, and capital are not satisfactory, and they could not pay all-round, effective support and service to the primary and secondary industry.

\section{The Development Paths of Modern Services Industry in Resource-Dependent Cities}

A. To further play our government's functional roles, and improve the development environment of modern service industry

In view of the current situation, the resource-dependent cities should give full play to their roles, strengthen the development planning, policy and regulation, investment and construction of public services infrastructure. Enhance the units' competitiveness of the modern services industry, by scientific guidance, clear the division and cooperation of economies in the region. And it needs taking positive policy on Land, investment, finance and taxation, to increase policy support and define the modern services by law. Optimizing the development environment and providing information to the public, create a fair and orderly market competition environment, which effectively protect the lawful rights and interests of the investors and workers. We need to eliminate all barriers of system and mechanism, break monopoly and rights, to clear the business requirement and qualifications, enlarge 
the scale and numbers of modern services enterprises. Then the competitive landscape of multi-economic agents was built, which improves the development of the modern services of resource-dependent cities.

\section{B. To implement the diversification strategy in modern services industry}

The resource-dependent cities should positively develop diversified and rationalized industries, optimize the proportion of industrial structure. The optimization of the industrial structure is the result of automatically build among the third industries, and the changes will reconstruct their relationship. For the dependence on the resource, the industrial structures are unreasonable, heavy-industry is in a high proportion, which needs to transfer the function to downstream firms, enlarge the scale, promote its development level, mix the trend together. The prominent function of the modern services to the economic society are needed, too. These cites should comprehensively consider the national policies, resources, market demand, etc. The information services, modern logistics industry, financial industry, researching technology, tourist culture industry, etc,should adopt the dislocation development seamless joint, to raise levels, scale and grade. With the focus on developing modern services, trying best to reduce dependence on resources, give consideration to the relationship of advanced manufacturing, agriculture and services[2].On the basis of complementary in industry, strengthen the regional competition advantages, promote the regional economic in health development, and achieve sustainable and healthy development to services clustering.

\section{To attach great importance on training talents, and provide intellectual support for modern services development}

The modern services productivity depends on the rational use of human capital. The resource-dependent cities should improve the talent policy, education policy, education and training resources, to strengthen the university, research institutes, vocational colleges and some other social institutions' cooperation. The next, improve job and technical training, enhance the overall quality of employees, cultivate a batch of compound talents who have the innovation ability, train some opening talented person who knows the International regulations, and some high skilled talents that adopt the market requirements. The third, establish the talent flow and talents stimulating mechanism, perfect import funnel. Open the service sector to foreign investment, to engage highgrade specialized talents oversea, try all kinds of service innovation with their help, improve the enterprise management level ,then the domestic modern service industry. The last, to strengthen the racking service in the use of talents, perfect the system of employment, complete the talents resource allocation, that could offer talents protection. To cultivate creative talents in informational counseling, research and development, establish talents' database and talents' service institutions of modern services[3].
D. To accelerate the opening, expand developing space of the modern services industry

The modern services enlarge the open field, which need to make good use of domestic and international markets, absorb and utilize the capital, technology, talents, and management experience. All of them are the important parts of development and competitiveness. Opening wider to the outside world, the resource-dependent cities should seize the opportunity of world economic structure adjustment and the transfer to developing countries. To take full advantage of the market demand, better investment environment, the low labor cost, then actively accept the service international transformation. Timely, study the international advanced services technology, service theories, management and methods, draw lessons from the successful practice, offer preferential policies, and attract the multinational companies, which could promote the institution and management innovations. Reform and create, cultivate some competitive advantage service outsourcing companies to be global, speed up the training of leading service enterprises, depend on the market research and information consultant, etc, which support the leading export-oriented enterprises to take part in the international competition[4].

E. To enhance the innovation of system and mechanism, improve socialization, marketization level of modern service industry

Development speed of modern service mostly depends on the market demand. The resource-dependent cities should introduce the market mechanism and competition mechanism, speed up the marketization, socialization, and industrialization. Through the deepening and upgrading, the social specialization increases much higher, it increases the enterprises' internal service activities to be external, and the service trade is to be marketization. The government should set up a good external platform, to promote state-owned service enterprises into transformation and promotion, establish and improve the modern corporate system, for such enterprises in competitive fields should implement stock share reconstruction, to become a real market subject in the competition. Finally, to create fair market competition. Through the mergers and reorganization, etc, to develop a group of large-scale service enterprises or enterprise groups, that they should own proprietary brand,work by taking the capital as the link, be cross-regional and cross-industry, to rise in international competitive capacity[5].

\section{Conclusion}

Rapid development of modern service industry in resource-dependent cities puts forward newer and higher requirements, along with transformation and upgrading of economic and adjustment of industrial structure. The resourcedependent cities must vigorously develop modern service industry by changing ideas, updating concepts, and prominent position of the modern service industry in the industrial structure, in order to enhance urban quality and competitiveness. Therefore, the only way for the future 
resource-dependent cities is developing and strengthening the modern service industry.

\section{Acknowledgment}

This research as a stage achievement of the educational science research special subjects for 2013, Hebei province "twelfth five-year" planning, modern service industry development and high quality technical skilled personnel training research. Project number:13020014.

\section{References}

[1] Li Zhiping. Research on the Dynamic Mechanism of Modern Service in Industries Areas Formation and Development. Tongji University, pp.1011,2008

[2] Liu Xufang. The Fusion Research on Modern Service Industry. Capital Economic \& Trade University of Beijing,pp.114-117,2010

[3] Xu Guanhua. The Developing Trend and Design Measures of Modern Service Industry. Strategy and Decision-Making Research,,pp.253,2009

[4] Wang Zhongyao, etc. The strategic thinking of modern service industry in our country. Guangming Daily.2008

[5] Li Haitong. Research on Modern Service Development of the Capital Economy Region. Cooperation in Economy and Technology, December, 2012 